\title{
Magnetic resonance (MR) imaging of the carpal tunnel and related structures in New Zealand Rabbit (Oryctolagus cuniculus): An anatomic and radiologic evaluation on an animal model
}

\author{
Okan EKİM ${ }^{1}$, Çağdaş OTO ${ }^{1}$, Oktay ALGIN ${ }^{2}$ \\ ${ }^{1}$ Ankara University Faculty of Veterinary Medicine Department of Anatomy, Ankara; ${ }^{2}$ Atatürk Training and Research Hospital, \\ Department of Radiology, Bilkent, Ankara, Turkey.
}

Summary: The aim of this study was to determine the anatomical structures in carpal region with the routine T1, T2 weighted (W) and three-dimensional (3D) magnetic resonance (MR) sequences that are frequently being used for the diagnosis and the treatment of the wrist disorders and to indicate the efficacy of MR imaging (MRI) on the rabbit's carpal region which can be a convenient wrist model especially for the carpal tunnel syndrome. It is also aspired to compare the image features obtained from 1.5 and 3 Tesla MR units in terms of anatomy and radiology. Five adult New Zealand rabbits were used in this study. Wrists were scanned in neutral position by 1.5 and 3 Tesla MR devices with a loop coil and a 15-channel transmit-receive birdcage coil respectively. Anatomy of the carpal tunnel was well defined in T1W transverse images in 1.5 Tesla MRI. The median nerve was imaged with greater signal intensity on T2W sequences. In 3 Tesla MRI, the anatomical structures in carpal region could easily be evaluated on high resolution 3D sequences with isotropic voxels and also with the help of thin section reformatted images. According to our results, 3D sequences with isotropic voxel sizes by 15-channel transmit-receive birdcage coil in 3 Tesla MRI device seems to be more efficient than the other routine two-dimensional sequences in 1.5 Tesla MRI for the assessment of carpal tunnel anatomy, diagnosis and treatment of disorders both in humans and in animals. This process also decreases the MRI time and specific absorption rate (SAR) values.

Keywords: 15 channel transmit-receive coil, anatomy, carpal tunnel, magnetic resonance imaging, rabbit.

\section{Yeni Zelanda Tavşanı'nda (Oryctolagus cuniculus) karpal tünel ve ilişkili yapıların manyetik rezonans (MR) görüntülenmesi: Hayvan modeli üzerinde anatomik ve radyolojik bir değerlendirme}

Özet: Bu çalışmanın amacı; el bileği bölgesindeki rahatsızlıkların teşhis ve tedavisinde kullanılan rutin T1, T2 Ağırlıklı (A) ve 3 boyutlu manyetik rezonans (MR) sekanslarının yardımıyla, karpal bölgedeki anatomik oluşumları belirlemek ve manyetik rezonans görüntülemenin, özellikle karpal tünel sendromu için uygun bir bilek modeli olabilecek tavşan karpal bölgesi üzerindeki etkinliğine işaret etmektir. Ayrıca 1,5 ve 3 Tesla MR cihazlarından elde edilen görüntü özelliklerinin anatomik ve radyolojik açıdan karşılaştırılması da amaçlanmıştır. Bu çalışma için 5 adet Yeni Zelanda Tavşanı'ndan faydalanılmıştır. El bilekleri nötral pozisyonda sırasıyla 1,5 Tesla MR cihazında, halka tipi koil ile ve 3 Tesla MR ünitesinde, 15 kanallı alıc1-verici kafes tipi koil ile tarandı. 1,5 Tesla MR görüntülemede; T1 A transversal imajlarda carpal tünel daha iyi belirlendi. T2 A sekanslarda nervus medianus yüksek sinyal yoğunluğu gösterdi. 3 Tesla MR görüntülemede; karpal bölgedeki anatomik yapılar izotropik vokselli 3 boyutlu sekanslar ve ayrıca ince kesit reformat görüntülerin de yardımıyla rahatlıkla değerlendirilebildi. Sonuçlarımıza göre; hem insan hem de hayvanlarda karpal tünel anatomisinin değerlendirilmesi, rahatsızlıkların teşhis ve tedavisi için izotropik voksel 3 boyutlu sekanslar ve 15 kanal alıcı-verici koil vasıtasıyla çekilen 3 Tesla MR görüntülemenin, 1,5 Tesla MR görüntülemede kullandığımız 2 boyutlu sekanslara göre daha etkin olduğu görülmektedir. Ayrıca bu işlem MR görüntüleme zamanını kısaltmakta ve SAR değerlerini de düşürmektedir.

Anahtar Kelimeler: 15 kanallı alıc1-verici koil, anatomi, karpal tünel, manyetik rezonans görüntüleme, tavşan.

\section{Introduction}

Carpal tunnel is a fibro-osseous canal on the palmar side of the wrist and it is surrounded by carpal bones and flexor retinaculum (11). Median nerve and flexor tendons of the fingers pass through this canal (21). This region has an importance for many investigators on account of the carpal tunnel syndrome which is the most common compression neuropathy for the humans (5, 9, 19). Despite a rapidly increasing prevalence and causing a serious economic loss, the etiology is frequently described as idiopathic and the diagnosis and treatment are not satisfying in some of the patients $(4,8,9)$.

The carpal tunnel anatomy of the rabbit has been reported by several authors and it is similar to man 
regarding the osseous and connective tissue formations in this region $(3,10,13,18)$. The carpal joint of rabbit consists of four bones in the proximal row, radial, intermediate, ulnar, and a small accessory carpal bone and another four in the distal row, the carpal bones from $1^{\text {st }}$ to $4^{\text {th }}$, which are attached to each metacarpal except the fifth (10). The only dissimilarity to human wrist is the central carpal bone in between the $2^{\text {nd }}$ and $3^{\text {th }}$ carpal bones (18). The median artery and the median nerve pass through the carpal tunnel together with the tendons of deep and superficial digital flexor muscles $(7,10,18)$. The flexor pollicis longus of the rabbit is also within the carpal tunnel. The proximal and distal rows of carpal bones and the transverse carpal ligament form a rigid passageway at the wrist through which the flexor tendons and the median nerve pass downwards (18). Due to those mentioned above, rabbit seems to be a convenient model for the researchers working on physiopathology of the carpal region.

Magnetic resonance (MR) imaging (MRI) distinguishes as an effective non-invasive method not only for the anatomy of the structures in carpal tunnel, but also for the diagnosis, treatment and staging of carpal tunnel syndrome and many other disorders both in human and veterinary medicine $(2,16,17,20,23)$. MRI provides an objective and typical morphological data and this is directly related with the period and the intensity of the diseases in carpal region (2).

But at the same time, imaging of the carpal region in rabbit is quite difficult with the routine MRI coils and sequences due to the low quantity of the body fluids, scantiness of soft tissues and the narrowness of field of view. Therefore, the necessity of a small but modified coil for the specific parts of the body or an improved multi-channel coil, and special MRI sequences becomes more important in this region of small animal models.

The aim of this study was to determine the anatomical structures in routine T1, T2 weighted and three-dimensional (3D) MR sequences that are frequently being used for the diagnosis and the treatment of the wrist disorders and to indicate the efficacy of MRI for the anatomy of rabbit's carpal region as a wrist model. It is also aspired to compare the image features obtained from 1.5 and 3 Tesla MR devices. According to our survey on previous researches, a current study in which the isotropic 3D sequences and MR devices had been used for the evaluation of the wrist on animal models could not be found.

\section{Materials and Methods}

Three male and 2 female adult New Zealand rabbits which had been practiced previously on another research were also used in this study. MRI process was performed for both left and right forelimbs within 15-30 minutes after euthanasia procedure.

Wrists were scanned in neutral position by 1.5 Tesla (Magnetom Vision Plus, Siemens Medical Solutions, Erlangen, Germany) MR device with a $40 \mathrm{~mm}$ loop coil and 3 Tesla (Tim Trio, Siemens Medical Solutions, Erlangen, Germany) MR unit with 15-channel transmitreceive birdcage coil. Firstly, three planes scout (localizer) images were obtained in both 1.5 Tesla and 3 Tesla devices.

Table 1. Parameters of 1.5 Tesla MR sequences. Tablo 1. 1,5 Tesla MR sekanslarının parametreleri.

\begin{tabular}{lcc}
\hline Sequence Parameters & 2D T1W & 2D T2W \\
\hline TR $(\mathrm{ms})$ & 400 & 2900 \\
TE $(\mathrm{ms})$ & 20 & 96 \\
FOV $(\mathrm{mm})$ & $50 \times 50$ & $50 \times 50$ \\
Matrix & $192 \times 256$ & $210 \times 256$ \\
NEX & 2 & 2 \\
Slice Thickness $(\mathrm{mm})$ & 2 & 2 \\
ETL & 1 & 1 \\
Time of Acquisition & 3.27 min & $3 \mathrm{~min}$ \\
\hline
\end{tabular}

Routine two dimensional (2D) T1 and T2 weighted (W) sequences were performed with the 1.5 Tesla MR device (Table 1). In 3 Tesla MRI, after acquisition of three planes, $\mathrm{T} 1 \mathrm{~W} / \mathrm{T} 2 \mathrm{~W} /$ proton-density $\mathrm{W}$ routine turbo

Table 2. Parameters of 3 Tesla MR sequences.

TSE: turbo spin-echo; VIBE: volumetric interpolated breath-hold sequence; FLASH: fast low-angle shot; SPACE: sampling perfection with application-optimized contrasts by using different flip angle evolutions.

Tablo 2. 3 Tesla MR sekanslarının parametreleri.

TSE: turbo spin-echo; VIBE: volumetric interpolated breath-hold sequence; FLASH: fast low-angle shot; SPACE: sampling perfection with application-optimized contrasts by using different flip angle evolutions.

\begin{tabular}{lccccc}
\hline \multicolumn{1}{c}{ Sequence Parameters } & 2D T1W-TSE & $\begin{array}{c}\text { 2D T2W-TSE } \\
\text { (dual echo) }\end{array}$ & 3D-VIBE & 3D-FLASH & T2W 3D-SPACE \\
\hline TR $(\mathrm{ms})$ & 653 & 4530 & 14.7 & 17 & 1500 \\
TE $(\mathrm{ms})$ & 29 & 90 & 6.52 & 5.9 & 121 \\
FOV $(\mathrm{mm})$ & $64 \times 38$ & $27 \times 53$ & $51 \times 54$ & $230 \times 120$ & $162 \times 45$ \\
Matrix & $384 \times 182$ & $320 \times 120$ & $320 \times 273$ & $640 \times 120$ & $512 \times 146$ \\
Slice Thickness (mm) & 0.33 & 1.1 & 0.2 & 0.2 & 0.6 \\
ETL & 3 & 14 & 1 & 1 & 129 \\
Number of Images & 57 & 10 & 144 & 128 & 64 \\
\hline
\end{tabular}


spin-echo, coronal plane T1W 3D-spoiled gradient-echo and fast low-angle shot (FLASH), sagittal plane 3D-T1W volumetric interpolated breath-hold (VIBE), and sagittal plane T2W 3D sampling perfection with application optimized contrasts using different flip-angle evolutions (SPACE) images were obtained with isotropic voxels (Table 2).

The MRI process for the each wrist took 20 minutes approximately. The volumetric data obtained from the 3D sequences in 3 Tesla MRI were transferred to the workstation of the MR device for the post processing with the Leonardo software (Siemens Medical Solutions, Erlangen, Germany). Three planes oblique-curved thin section reformatted and maximum intensity projection (MIP) images were created by this software. A group of radiologist and anatomists evaluated all the images in main and satellite consoles of MR device simultaneously.

\section{Results}

Considering the $\mathrm{T} 1 \mathrm{~W}$ transverse images in 1.5 Tesla MRI, anatomy of the carpal tunnel was well defined. The carpal bones and flexor retinaculum were hyperintense on T1W images (Figure 1). The superficial and deep flexor tendons had low signal intensity on both T1W (Figure 1) and T2W images (Figure 2). The osseous structures, especially the carpal bones, could be determined and labeled on all images (Figure 1 and 2). Flexor tendons could also be displayed on 2D T1W images (Figure 1). Besides, the median nerve was imaged with greater signal intensity on $\mathrm{T} 2 \mathrm{~W}$ sequences (Figure 2).

When examining the 3 Tesla MR images, the anatomical structures in carpal region could easily be evaluated on high resolution $3 \mathrm{D}$ sequences with isotropic voxels and also with the help of thin section reformatted images (Figure 3 and 4). The oblique and curved reformatted images provided convenience for the identification of all wrist elements such as tendons, bones and nerves (Figure 3). Although the images had been obtained with small FOV and isotropic 3D sequences, the quality of the thin section images were well enough due to their high resolution characteristics. Besides, the osseous structures and nerve-tendon sheaths were also determined with high confidence by the help of MIP images. In 3D FLASH and 3D VIBE images, it was quite convenient to display the hypointense formations such as tendons (Figure 3 and 4).

\section{Discussion and Conclusion}

When considering the images anatomically, the anatomic localization of the proximal and distal rows of the carpal bones displayed in MR images was congruent with the atlases and the other references $(7,13,18)$. T1W images can be used to determine the flexor tendons and bones. Besides, T2W ones are more effective for the anatomic identification of the median nerve and also its neuropathies such as synovial fluid-bone edema, mentioned by Cheng et all. (6). The anatomic localization of the median nerve could be identified on $\mathrm{T} 2 \mathrm{~W}$ images in 1.5 Tesla MR device. Despite that, the course of this nerve could be observed much more clearly in $3 \mathrm{D}$ reformatted images obtained by 3 Tesla device. These anatomic analyses mentioned above can be quite useful for the clinicians as well particularly performing the endoscopic surgical techniques.

MRI of the rabbits' carpal region was carried out with both 1.5 Tesla and 3 Tesla MR devices. However, a sophisticated high resolution (3 Tesla) device obviously provided us to obtain more detailed and well defined images. There has been a significant increase in the signal to noise ratio (SNR) values of the MR images with the widespread using of the 3 Tesla MR units in routine clinical applications (22). This increasing can not only be used to improve the image quality, but also make use to increase spatial resolution or to decrease the scanning time (12). This feature was considered in our study and practiced on 3 Tesla MR device with various sequences.

The most notable disadvantage of the 3 Tesla MRI is the high specific absorption rate (SAR) (14). However, this disadvantage could be eliminated by using $3 \mathrm{D}$ turbo spin-echo sequences such as 3D sampling perfection with application optimized contrasts using different flip-angle evolutions (3D-SPACE) as mentioned by Mugler $3^{\text {rd }}$ et all (14). T1W, T2W, proton-density $\mathrm{W}$, inversion recovery, and heavily $\mathrm{T} 2 \mathrm{~W}$ images could be obtained in a shorter time with high SNR and lower SAR by 3DSPACE sequence in accordance with the mentioned in previous researches $(12,14)$.

Isotropic 3D acquisition with high spatial resolution provides an advantage to evaluate the complex anatomical structures in the wrist, as observed in our study. The high resolution - thin section reformatted images obtained with the isotropic 3D sequences make possible to evaluate the patients or structures even after imaging by comparing with the other sequences.

Also the other advantage of $3 \mathrm{D}$ sequences with 3 Tesla MR unit is to decrease MR examination time significantly (1). In routine MR examination protocol, T1W and T2W sequences have to be performed in many plans to determine the anatomical structures in wrist. However, the morphological data given by these sequences could be obtained easily with the isotropic 3D sequencing itself as mentioned in our study. This 3D protocol shortens the process approximately 15 minutes for each MRI examination.

We have practiced loop coil in 1.5 Tesla device and also the 15 channel transmit-receive coil in 3 Tesla device as mentioned before. Besides, we had a chance to 

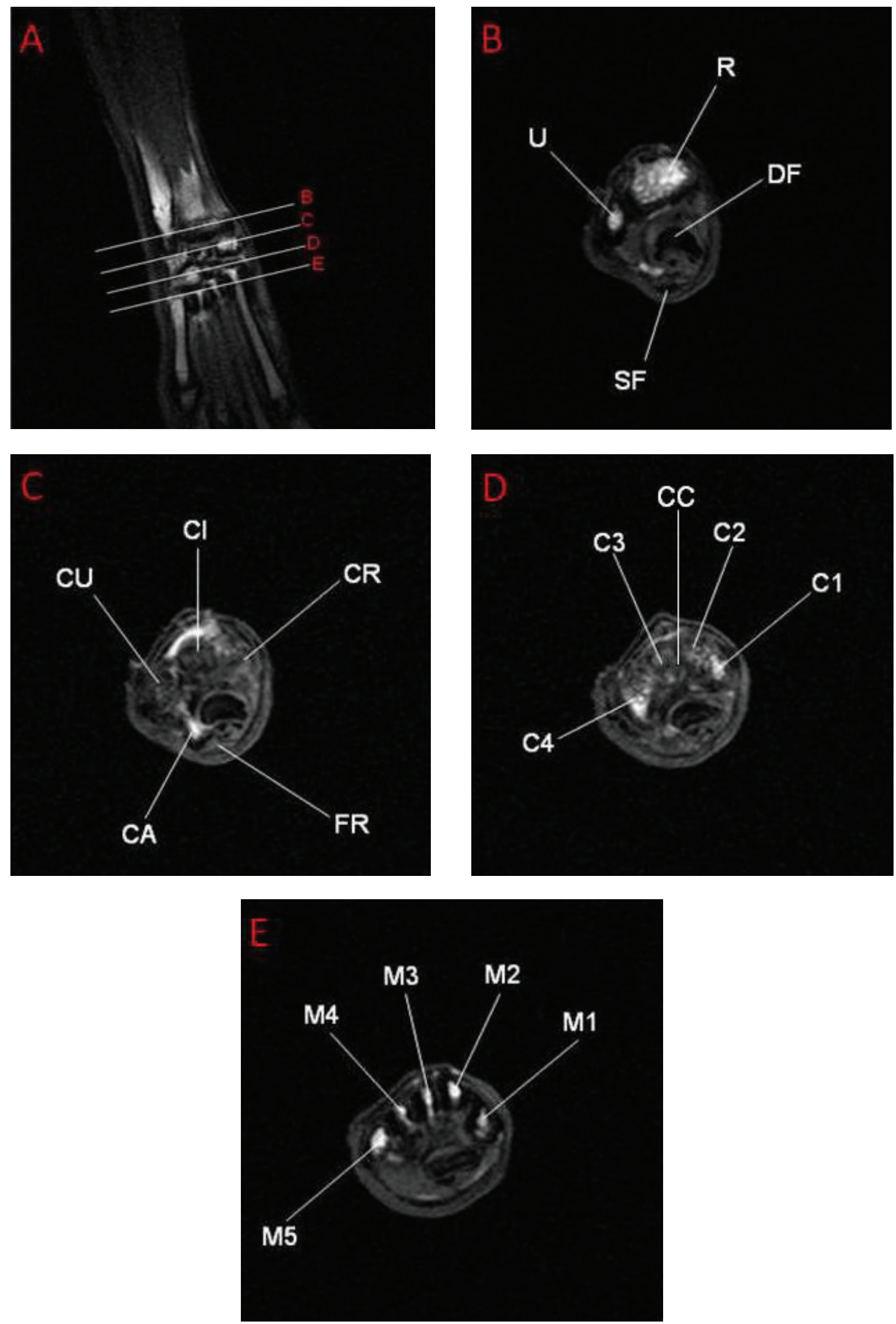

Figure 1. T1 weighted images of the right wrist scanned with 1.5 Tesla MR device. Male rabbit. A: Dorsal plane image on which the level of transverse images were labeled as B, C, D and E from proximal to distal. Şekil 1. Sağ bileğin 1,5 Tesla MR cihazında taranmış, T1 ağırlıklı görüntüleri. Erkek tavşan

A: Transversal görüntü düzeylerinin B, C, D ve E olarak proksimalden distale etiketlendiği dorsal görüntü. 

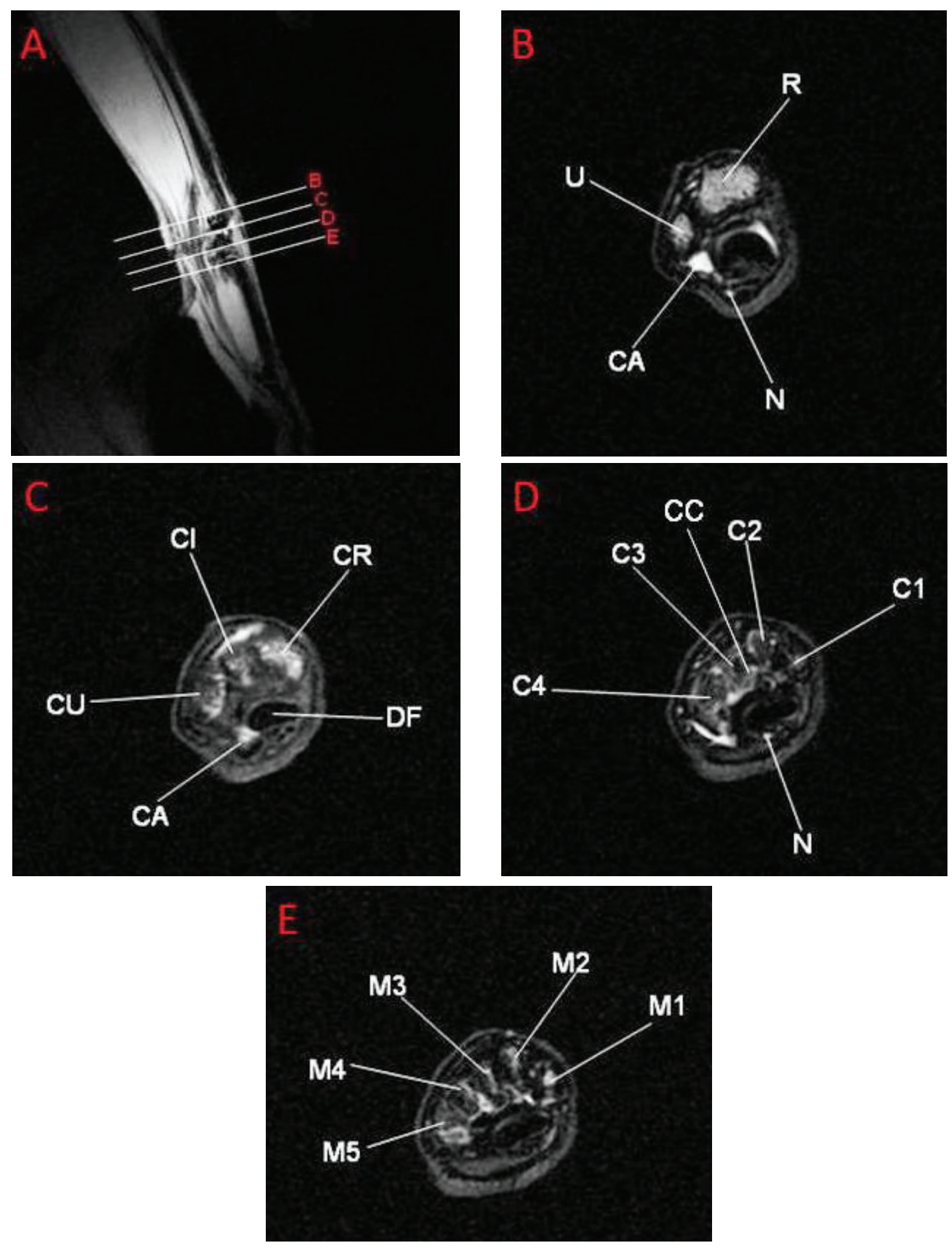

Figure 2. T2 weighted images of the right wrist scanned with 1.5 Tesla MR device. Male rabbit.

A: Sagittal plane image on which the level of transverse images were labeled as B, C, D and E from proximal to distal, Şekil 2. Sağ bileğin 1,5 Tesla MR cihazında taranmış, T2 ağırlıklı görüntüleri. Erkek tavşan.

A: Transversal görüntülerin B, C, D ve E olarak proksimalden distale etiketlendiği sagittal görüntü.

Acronyms of Figure 1 and 2: R: Radius, U: Ulna, DF: Deep flexor tendon, SF: Superficial flexor tendon, N: Median nerve, CR: Radial carpal, CI: Intermediate carpal, CU: Ulnar carpal, CA: Accessory carpal bones, FR: Flexor retinaculum, C1: $1^{\text {st }}$ carpal, C2: $2^{\text {nd }}$ carpal, C3: $3^{\text {rd }}$ carpal, C4: $4^{\text {th }}$ carpal bones, M1: $1^{\text {st }}$ metacarpal, M2: $2^{\text {nd }}$ metacarpal, M3: $3^{\text {rd }}$ metacarpal, M4: $4^{\text {th }}$ metacarpal, M5: $5^{\text {th }}$ metacarpal bones.

Şekil 1 ve 2'ye ait Akronimler: R: Radius, U: Ulna, DF: M. flexor digitorum profundus'un tendo'su, SF: M. flexor digitorum superficialis'in tendo'su, N; Nervus medianus, CR: Os carpi radiale, CI: Os carpi intermedium, CU: Os carpi ulnare, CA: Os carpi accessorium, FR: Retinaculum flexorum, C1: Os carpale primum, C2: Os carpale secundum, C3: Os carpale tertium, C4: Os carpale quartum, M1: Os metacarpale primum, M2: Os metacarpale secundum, M3: Os metacarpale tertium, M4: Os metacarpale quartum, M5: Os metacarpale quintum. 


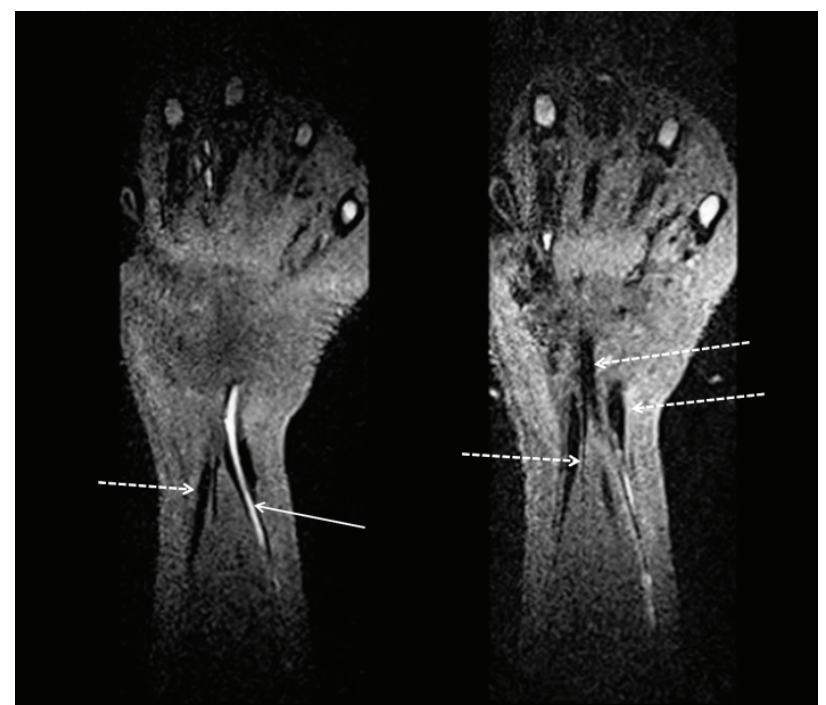

Figure 3. Coronal plane 3D-FLASH images of wrist in female rabbit scanned with 3 Tesla MR device. On these images, median nerve was seen as hyperintense (arrow), and tendons were imaged as hypointense (broken arrows).

Şekil 3. Dişi tavşanda, bileğin koronal planda ve 3 Tesla MR'da elde edilmiş 3D-FLASH görüntüleri. Nervus medianus hiperintens (düz ok), tendonlar ise hipointens (kesikli oklar) görünümdedir.

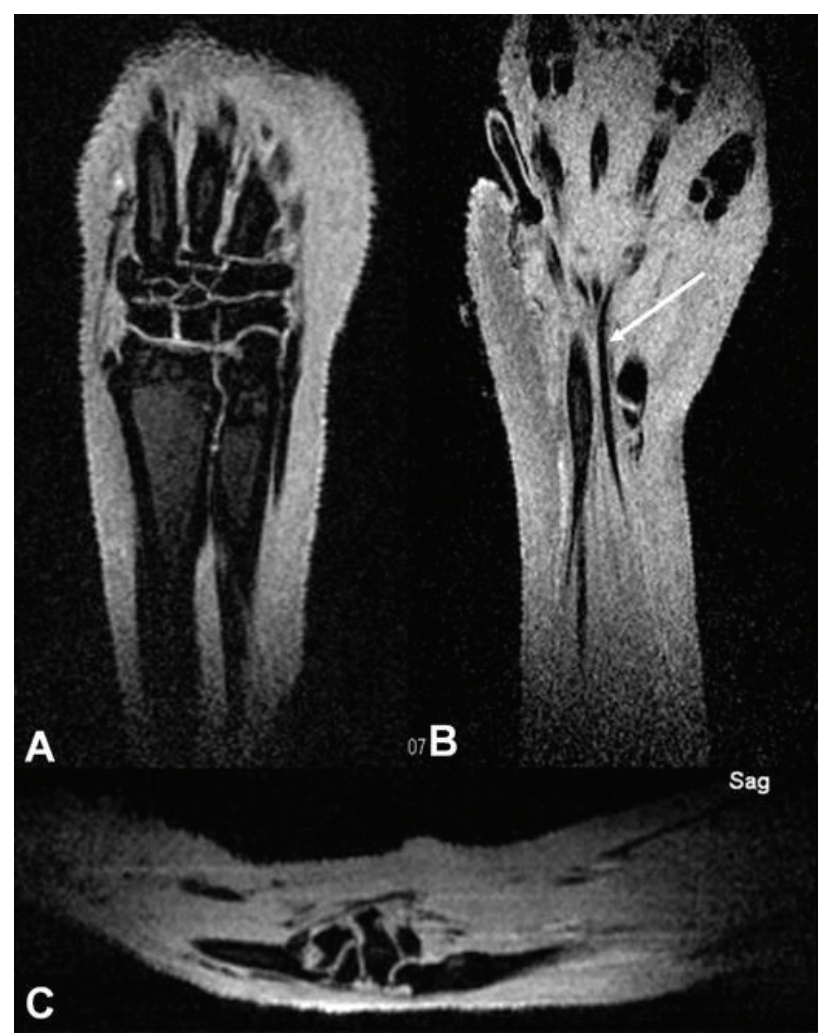

Figure 4. 3D-VIBE images of the wrist in female rabbit on coronal (A, B) and oblique sagittal (C) planes. Bone cortex (in $\mathrm{A}$ and $\mathrm{C}$ ) was imaged as hypointense. However, bone marrow (in A) was isointense. Flexor tendons could be displayed as hypointense (white arrow)

Şekil 4. Dişi tavşanda, bileğin koronal (A, B) ve oblik sagittal (C) planlarda alınmış 3D-VIBE görüntüleri. Kemik korteksi (A ve C'de) hipointens görüntülendi. Buna karşın kemik iliği (A'da) izointens görünümdeydi. Fleksor tendo'lar ise yine hipointens olarak görüntülendi (beyaz ok). try different coils with various sequences during 3 Tesla MRI process. However we could not obtain a satisfying image quality with the other coils. An optimal MR image of the carpal region was rather difficult with the routine clinical coils which have currently been used in human medicine (20). It was clearly seen that researchers who are planning this kind of studies, especially suchlike regions on laboratory animals, should prefer expedient coils. Thus they can obtain more qualified images.

When compared with the previous MR researches, one of the most important superiority and difference of our study was to use of 15 channel transmit-receive birdcage coil. With the usage of this coil in 3 Tesla MR unit, the $3 \mathrm{D}$ data which is composed from isotropic voxels smaller than $1 \mathrm{~mm}$ could be obtained with high SNR. The quality and resolution of the multiplanar images obtained from this data was notably high. Because the all sequences that we've used, were composed from submilimetric isotropic voxels. The devices and the techniques we've mentioned above are generally used in such cases that require high resolution such as human knee pathologies (15).

In conclusion, rabbit can be an effectual animal model to evaluate the anatomic and radiologic features on the carpal region. Before the interventional surgical procedures which will be performed in rabbit's carpal region, the visual data obtained from MR images can be quite useful in terms of anatomy and surgery. According to our results, isotropic 3D sequencing with high SNR in 3 Tesla MRI systems seems to be more efficient than the other routine two-dimensional sequences in 1.5 Tesla MRI for the assessment of carpal tunnel anatomy, diagnosis and treatment of disorders both in humans and in animals. Besides, this technique decreases the MRI time and SAR values. Either 1.5 or 3 Tesla MRI, the thing that matters is to find the most convenient coil and more important than that is to optimize the MR sequences.

\section{References}

1. Algin O, Turkbey B (2012): Evaluation of aqueductal stenosis by $3 D$ sampling perfection with applicationoptimized contrasts using different flip angle evolutions sequence: preliminary results with $3 T$ MR imaging. Am J Neuroradiol, 33, 740-746.

2. Bagatur EA, Zorer G, Oral B (2002): The role of magnetic resonance imaging in carpal tunnel syndrome: Correlation of clinical, electrodiagnostic and intraoperative findings and staging. Acta Orthop Traumatol Turc, 36, 2230.

3. Barone P, Pavaux C, Blin PC, Cuq P (1973): Atlas d'anatomie du lapin. Atlas of rabbit anatomy. Masson \& Cie Editeurs, Paris.

4. Bland JD (2005): Carpal tunnel syndrome. Curr Opin Neurol, 18, 581-585.

5. Bower JA, Stanisz GJ, Keir PJ (2006): An MRI evaluation of carpal tunnel dimensions in healthy wrists: 
Implications for carpal tunnel syndrome. Clin Biomech, 21, 816-825.

6. Cheng XG, You YH, Liu W, Zhao T, Qu H (2004): $M R I$ features of pigmented villonodular synovitis (PVNS). Clin Rheumatol, 23, 31-34.

7. Craigie EH (1969): Practical Anatomy of the Rabbit. University of Toronto Press, Toronto.

8. de Krom MC, Knipschild PG, Kester AD, Thijs CT, Boekkooi PF, Spaans F (1992): Carpal tunnel syndrome: prevalence in the general population. J Clin Epidemiol, 45, 373-376.

9. Diao E, Shao F, Liebenberg E, Rempel D, Lotz JC (2005): Carpal tunnel pressure alters median nerve function in a dose-dependent manner: a rabbit model for carpal tunnel syndrome. J Orthop Res, 23, 218-223

10. Ettema AM, Zhao C, An KN, Amadio PC (2006): Comparative anatomy of the subsynovial connective tissue in the carpal tunnel of the rat, rabbit, dog, baboon, and human. Hand (N Y). 1, 78-84

11. Farooki S, Ashman CJ, Yu JS, Abduljalil A, Chakeres D (2002): In vivo high-resolution MR imaging of the carpal tunnel at 8.0 tesla. Skeletal Radiol, 31, 445-450.

12. Haystead CM, Dale BM, Merkle EM (2008): $N / 2$ ghosting artifacts: elimination at 3.0-T MR cholangiography with SPACE pulse sequence. Radiology, 246, 589-595.

13. McLaughlin CA, Chiasson RB (1990): Laboratory Anatomy of the Rabbit. Brown Publishers. Dubuque, IA, USA.

14. Mugler $3^{\text {rd }}$ JP, Wald LL, Brookeman JR (2001): T2weighted $3 D$ spin-echo train imaging of the brain at 3 tesla: reduced power deposition using low flip-angle refocusing $R F$ pulses. Proc Intl Soc Mag Reson Med, 9, 438.

15. Notohamiprodjo M, Horng A, Kuschel B, Paul D, Li G, Raya JG, Reiser MF, Glaser C (2012): 3D-imaging of the knee with an optimized 3D-FSE-sequence and a 15channel knee-coil. Eur J Radiol, 81, 3441-3449.
16. Oto Ç, Ekim O, Algin O, Şenel OO, İnce N, Hazıroğlu RM (2011): 3 Tesla Magnetic resonance imaging and multiplanar reconstruction of the brain and its associated structures in pig. Vet J Ankara Univ, 58, 75-78.

17. Pierre-Jerome C, Smitson RD Jr, Shah RK, Moncayo V, Abdelnoor M, Terk MR (2010): MRI of the median nerve and median artery in the carpal tunnel: prevalence of their anatomical variations and clinical significance. Surg Radiol Anat, 32, 315-322.

18. Popesko P, Rajtova V, Horak J (1992): Colour Atlas of Anatomy of Small Laboratory Animals Volume 1: Rabbit and Guinea Pig. Wolfe Publishing, London.

19. Silverstein, BA, Fine L.J, Armstrong TJ (1987): Occupational factors and carpal tunnel syndrome. Am J Public Health, 11, 343-358.

20. Smith DK (1993): Dorsal carpal ligaments of the wrist: normal appearance on multi planar reconstructions of three-dimensional fourier transform MR imaging. Am J Roentgenol, 161, 119-125.

21. Sobotta J, Becher H (1968): Atlas der Anatomie des Menchen. Urban \& Schwarzenberg, München.

22. Stehling C, Langer M, Bachmann R, Kraemer S, Kooijman H, Heindel W, Vieth V (2009): Three-tesla magnetic resonance imaging of the wrist: Diagnostic performance compared to 1.5-T. J Comput Assist Tomogr, 33, 934-939.

23. Steinbach LS, Smith DK (2000): MRI of the wrist. Clin Imaging, 24, 298-322.

Geliş tarihi: 27.02.2013 / Kabul tarihi: 29.04.2013

Address for correspondence:

Assoc. Prof. Dr. Çă̆daş OTO

Ankara University,

Faculty of Veterinary Medicine,

Department of Anatomy,

Irfan Baştuğ cad. 06110 Ankara-TURKEY

e-mail:coto@gmail.com 